\title{
"Rodear lo que se escapa": la microficción en el entramado de Solo queda saltar, de María Rosa Lojo
}

Gracielle Marques $^{1}$

Resumen. En Solo queda saltar (2018), María Rosa Lojo retoma al personaje Isolina, de El libro de las Siniguales y del único Sinigual (2016), y algunos símbolos presentes en Bosque de Ojos (2011), conectando imágenes e historias en una narrativa en expansión que, a su vez, expresa su particular interpretación del mundo fracturado por el exilio republicano gallego en Argentina. El presente trabajo propone una lectura interpretativa del método de composición novelesca desde la producción microficcional, teniendo en cuenta la fractalidad de las formas breves y la dialéctica real/virtual y olvido/memoria para el replanteamiento de su condición de hija de exiliados. Para eso, el estudio se basa en las reflexiones crítico-teóricas de Lauro Zavala (2006), Seligman-Silva (2008), Mariane Berissi (2014) y David Lapoujade (2018), entre otros.

Palabras clave: exilio español; hibridez genérica; literatura argentina contemporánea; memoria; microficción.

[en] "Solo queda saltar": the microfiction in the framework of Solo queda saltar, by María Rosa Lojo

Abstract. In Solo queda saltar (2018), María Rosa Lojo returns to the character Isolina from El libro de las Siniguales y del único Sinigual (2016), and some symbols present in Bosque de Ojos (2011) entangling images and stories in an expanding narrative that, in turn, expresses its particular interpretation of the world fractured by the Galician republican exile in Argentina. The present work proposes an interpretative reading of the method of novel composition from the microfictional production, taking into account the fractality of the short forms and the real / virtual dialectic and oblivion/ memory for the rethinking of her condition as the daughter of exiles. For that, the study is based on the critical-theoretical reflections of Lauro Zavala (2006), Seligman-Silva (2008), Mariane Berissi (2014) and David Lapoujade (2018), among others.

Keywords: Spanish exile; generic hybridism; contemporary Argentine literature; memory; microfiction.

Sumario. 1. Texturas rugosas 2. Brevedad y memoria: la necesidad de narrar 3. La mirada singular: las existencias nómadas, fronterizas e inacabadas 4. Palabras finales.

Cómo citar: Marques, G. (2021) Bolaño, Borges y la cultura de fin de siglo. Una lectura de La literatura nazi en América y Estrella distante, en Anales de Literatua Hispanoamericana 50, 73-82.

\section{Texturas rugosas}

Con Solo queda saltar (2018), la ficción de María Rosa Lojo sigue su construcción de un mundo propio, vinculado al exilio heredado y regido por un espacio-tiempo heterogéneo abarcador de la historia, del sueño, de la magia, de las pasiones e infortunios humanos. Esta novela integra su mirada puesta en el enfrentamiento con la identidad propia y también de su país, cifradas en tensiones centrales de su universo ficcional: el exilio, la búsqueda de identidad, la memoria, la traducción cultural y el regreso. En esta lectura me acerco a cuestiones que ponen en diálogo esta novela con la producción microficcional de la autora, en especial El libro de las Siniguales y del único Sinigual (2016) y algunas composiciones de Bosque de Ojos

\footnotetext{
${ }^{1}$ Universidad Federal de Rondonia, Porto Velho. Brasil.

Email: gracielle.marques@unir.com.br
} 
(2011), entre ellas: "La palabra muda", del apartado Visiones y "Transparencias" y "Ojos de Dios", de Esperan la mañana verde.

Así, divido el trabajo en tres partes. En la primera, discuto sobre la condensación y la expansión de la forma microficcional en la obra lojiana. En seguida, analizo la emergencia de la brevedad asociada a la fragmentación mnemónica del exiliado y la necesidad de narrar para sobrevivir. Por fin, planteo un abordaje sobre las existencias nómadas, fronterizas e inacabadas que protagonizan el trazado que establezco entre esos textos.

La naturaleza fragmentaria e intratextual de los textos de María Rosa Lojo invita al lector a encontrar distintos caminos interpretativos que permiten ver, por ejemplo, la incrustación de textos breves en otras narrativas: un hecho señalado por Lojo en más de una ocasión, cuando habla de algunas de esas formas en los orígenes de sus creaciones. Aun sin esa advertencia, el lector que circule por su bosque literario se dará cuenta de la fractalidad que se dibuja en su producción.

En la teoría del caos, un fractal es una entidad que reproduce su forma en su interior en una escala cada vez más pequeña. Para Lauro Zavala (2006), estudioso de la mini/microficción, esa posibilidad de relación auto-similar se aplica a muchas producciones que siguen el dibujo de esa geometría rugosa, por medio de series. Esta imagen metafórica de creación expansiva también es alcanzada por medio de la lectura. Aunque esa óptica fractal sea más bien empleada para leer una única obra o textos pertenecientes al mismo género, es posible ampliar esa idea para unir los hilos sutiles entre las microficciones y la producción novelística de Lojo.

Ese caso, al que muchos podrían llamar simplemente emblemas o tópicos recurrentes de la poética lojiana, aparece en muchas ocasiones en su obra. El proceso expansivo, que genera la auto-similitud, permite observar cómo algunas microficciones se difunden en otros territorios artísticos de la escritora y cómo un texto crea otro y una parte puede representar el todo, al modo de los fractales. En cuanto a los dilemas académicos en torno a la forma genérica de la microficción, en cierto modo, ponen en cuestión formas de pertenencia de una experiencia social, en este caso, la herencia del exilio republicano español de los padres en Argentina, que lleva a la autora a buscar soluciones estéticas para expresar las tensiones e inestabilidades de vivir entre dos mundos.

La correlación entre la microficción y los destellos de la memoria heredada del exilio, aunque aquella, para ganar al olvido, los contorne con recursos claramente ficcionales, nos lleva a otro territorio escurridizo, es decir, a las imprecisiones entre la ficción y la realidad en el discurso lojiano. Si bien no es mi intención teorizar esa relación, que además ha sido muy bien profundizada por Marcela Crespo Buiturón (2008), me parece importante señalar que entre los motivos de la producción literaria de los "exilados hijos", es decir, aquellos que han heredado el exilio paterno, están la (re)formulación de las huellas de lugares y los tiempos recordados y vividos. Como Lojo (2002: s/f) define: "Para el exiliado hijo el lugar de su nacimiento tiene a menudo la dudosa calidad de las copias platónicas, es un mundo 'de segundo grado', en tono menor, a punto de desvanecerse, deslucido e insuficiente". Ese efecto generado, en parte, por la espera traumática del retorno, anhelado por los padres, demuestra su profundo sentimiento del exilio y la insistencia por narrar situaciones protagonizadas por migrantes, el intento de establecer puentes con los orígenes, la sensación de pérdida e insuficiencia, pero quizás lo más importante: una escritura singular que no acepta el enclaustro de ninguna etiqueta genérica, pues se construye en un entre lugar genérico, desde el cual absorbe distintas tradiciones. Por eso, en un tenso equilibrio entre memoria y olvido, la poética lojiana se lanza a "rodear lo que escapa" (Lojo, 2011: 167).

Esas consideraciones son muy relevantes a la hora de sondear los sentidos que nos sugieren las hibridaciones entre formas genéricas realizadas en la obra de Lojo. Así, en las microficciones de María Rosa Lojo encontramos una inespecificidad (Garramuño, 2014) entre prosa y poesía que estiran aún más los límites de ese género y arruinan páginas y páginas teóricas de esquemas genéricos rígidos. En la antología $E l$ límite de la palabra: el microrrelato argentino contemporáneo (2007), que incluye textos de Lojo, Laura Pollastri hace un análisis del género microrrelato y coincide con otros críticos en que sus características son la brevedad, la narratividad, la fragmentación, la reescritura, el uso poético del lenguaje, la intertextualidad y el humor. Sin embargo, Pollastri (2007:18) reconoce que la narratividad funciona a medida que el lector se compromete a establecer la historia en la historia. En el caso de los textos microficcionales poéticos de Lojo, 
como ella los denomina, ciertos estímulos ${ }^{2}$ permiten al lector establecer la narrativa y no solo disfrutar de "un relámpago de percepción, una intuición o visión" instantánea, considerando la definición de David Lagmanovich (2016: 119) sobre el poema en prosa. En todo caso, como afirma Pollastri (2007: 18) preguntar sobre quién narra "garantiza la existencia de una narración, que el texto revela y oculta simultáneamente" y ese camino puede ser muy fructífero para la lectura de algunas microficciones de Lojo.

No es mi intención ahondar en la problematización de ese género, dinámico y plural, aunque sea conveniente remarcar que Bosque de Ojos (2011) -libro que congrega la microficción lojiana- es, en primer lugar, un libro que no posee un cuerpo textual específico, es decir, solo de microrrelatos, sino que contiene textos que habitan esta frontera porosa entre prosa y poesía y que pueden ser abrigados bajo la denominación más amplia de microficción (Lojo, 2011: 247). De manera general, las piezas no clasificables de Bosque de Ojos comparten algunas constantes del microrrelato, señaladas por Ana María Shúa (2017): el diálogo intertextual con la tradición, como podemos leer en "Dijo Lázaro, que volvió de entre los muertos", "Dijo Teresa (1915-1582)" "Amor constante"; el tema de las criaturas fantásticas ("Fragilidad de los vampiros", "Dragones", "Ojos de Dios") y los lugares imaginarios, en especial las del apartado "Historias del cielo". También leemos textos que destacan la estructura de caja china, como en "Estructuras de las casas", "Té de las cinco" y "Líneas", para poner ejemplos. Pero, las microficciones de María Rosa Lojo van más lejos. La tensión entre el silencio y las palabras, entre contar y ocultar, se acerca al análisis de la contradicción interna que hace Raúl Brasca (2000 s/f) al identificar en "Diálogos", de Alejandra Pizarnik, un "frustrar reiteradamente la pretensión de otorgar sentido; cada posibilidad de sentido es revocada en la línea siguiente".

En el grandioso bosque de ficción en miniatura de Bosque de Ojos, lo que me llama la atención, tal como lo menciona la autora en su epílogo, es la gran cantidad de términos que se refieren a los ojos y, más ampliamente, al campo de la óptica, la luz y el espejismo. La mirada, en estos fragmentos independientes, autónomos y proteicos, indica una poética en constante movimiento y mutación, en la que triunfa el perspectivismo; se centra en la búsqueda del momento inexplicable en que las cosas se diferencian y son engendradas. Por lo tanto, no se trata de enfatizar la mirada cartesiana, de exterioridad y superficialidad, predominante "sobre" los otros sentidos en nuestra era, sino de una mirada encarnada, envuelta y atravesada por movimientos inestables y contradictorios, que luchan contra la pretensión de las clasificaciones y fundamentos (Marques, 2019). Esta percepción vertical puede llevar al lector a preguntas importantes sobre su forma de ver la realidad.

En ese sentido, en las microficciones del apartado "Esperan la mañana verde", distribuidos bajo los títulos "Vampiros, dragones y otras metamorfosis", "Vida doméstica", "Viajes", "Canto madre", la vida, aparentemente ordinaria, está atravesada por lo que estaba oculto o al acecho en el inconsciente: en las líneas de la mano ("En una de las líneas de tu mano hay un puente que desemboca en el mar..."3), dentro o detrás de los objetos de la casa ("Detrás de un guante viejo había un hermano desaparecido..."), del maquillaje (“...se empolva las mejillas para que no las deñen los rayos de las fotografías y el hueco luminoso de los ausentes", ) o en una canción ("Hay un llamado inaudible, hay una música que podría volverte el alma del revés, si la escucharas"). La casa es uno de los espacios más explotados en las microficciones de ese apartado. Por las "[a]perturas" de la casa los secretos se anuncian, "[d]esde el jardín" los cuerpos humanos se entrelazan como el entorno vegetal y en el patio una "[t]ransparencia" provocada por canciones remotas comunica el cuerpo de una mujer con su pasado. Esas microficciones crean realidades teñidas por una atmósfera inusual y paradójica.

En la serie final, "Visiones", los límites entre los textos se difuminan. Estamos en un verdadero "bosque de imágenes". En el primer apartado, "Signos oscuros", el yo poemático "con pasos de cazador nocturno" (Lojo, 2011: 211) nos guía al reverso del mundo en dónde es mirado por un olvidado y perdido mundo original. En el segundo texto, el "faro desnudo, de murallón levantado en la más alta noche" (Lojo, 2011: 212) expresa una soledad y anhelo profundo de un pasado clausurado y suspendido que, enlazándose con el siguiente texto, golpea al "tú" "arrojado a la insaciable soledad del mundo" (Lojo, 2011: 213). En las siguientes microficciones vemos un "campo arrasado, por el terrible campo de una guerra donde nadie se ha

\footnotetext{
${ }^{2}$ Me refiero sobre todo al trabajo de construcción de una estructura de pensamiento cercana a la del sueño, en la cual entramos en un espacio-tiempo de representación conflictiva entre imágenes e ideas, proveniente de vestigios diurnos que toman diferentes direcciones e involucran situaciones internas y pasadas, como podemos leer en las secciones de "Visiones" y "Forma Oculta del mundo".

${ }^{3}$ Ésta y la siguiente cita pertenecen, respectivamente, a las microficciones "Líneas" y "Estructuras de la casa" del apartado "Vida doméstica"

${ }^{4}$ Ésta y la siguiente cita pertenece, respectivamente a las microficciones "Maquillaje" y "Té de las cinco" del apartado "Vampiros, dragones y otras metamorfosis".
} 
cuidado de enterrar a los muertos" (Lojo, 2011: 214). Esos muertos, visto por un campesino, marchan "por el camino invertido [...] con sus mantos en derrota y sus largos pies de animales viajeros" (Lojo, 2011: 215), en una imagen próxima al poema "Extranjera en su patria" (Follas novas, 1880), de Rosalía de Castro. La muerte de jóvenes guerreros que aparecen en el apartado siguiente puede estar relacionada, según la lectura de Crespo Buiturón (2008: 109) con "la guerra de Malvinas, acaecida dos años antes de la publicación del libro". En el primer texto, del apartado "De los amados" la casa familiar en Galicia es recorrida por el padre solitario en una la canción "de las dolientes cosas conocidas" que sueña con el jardín del Norte.

El libro de las Siniguales y del único Sinigual (2016), con relación a su género va por "la misma vena "micro" y poética de los textos de Bosque de Ojos, según señala Cristina Piña (2010: 47), quien también lo califica como "una creación grandiosamente mínima que, además, es una creación típicamente femenina". Las diez partes en que se divide el libro ponen en juego nuestras estrategias de interpretación, permitiendo que sea leído, entre otras posibilidades, como una serie integrada, cuyo detalle fractal contiene rasgos genéricos, estilísticos y temáticos que comparten entre sí (Zavala, 2006).

El libro amalgama las oscilaciones entre la prosa poética de Lojo y la visión entre lo real y lo onírico ${ }^{5}$ utilizado en las diapositivas fotográficas de la doble página por la artista Leonor Beuter, hija de la escritora. Esta composición híbrida ciertamente cautiva al lector de todas las edades. La conjunción de los lenguajes usados para contar la historia de seres fantásticos nos pide apreciar su interacción textual y plástica para revelar los sentidos sutiles que posee, a la luz de las resonancias culturales e históricas relacionadas con el mundo mágico y la inmigración gallega.

De naturaleza paradójica y propiedades únicas, estos seres pequeños e inclasificables fueron encontrados por Isolina, una niña de Fisterra (Galicia), que los bautizó como Siniguales. Cuando era niña, Isolina intentó capturar a una Sinigual, pero sin éxito, porque la criatura huyó en su barca. Desde que emigró de su tierra natal los ha estado buscando incansablemente. En el momento de la enunciación, Isolina es una señora que vive en las afueras de Buenos Aires, conmovida por el deseo íntimo de reconectarse con sus Siniguales. Lo que ella no sabe es que la acompañaron al exilio; habitan su hogar y son responsables de las pequeñas cosas extrañas que suceden en él.

La vida de la niña/anciana cruza caminos invisibles con los de esas criaturas. Isolina comparte orígenes celtas remotos con ellos. Su nombre deriva de Isolda, una princesa irlandesa. Sin embargo, no se nos dicen muchos más detalles sobre la niña/anciana. Esto se justifica en parte por la brevedad característica del texto verbal en este soporte, además del carácter poético del texto, que toma la palabra justa y primorosamente alineada con las imágenes, en un ejercicio creativo de inventar nuevas formas de imaginar y representar los pliegues de la memoria.

El texto poético e ilustrado se hace eco de diferentes referencias culturales y literarias y se acerca a la propuesta poética y surrealista del libro ilustrado Le Cœur de Pic, compuesto por treinta y dos poemas de la escritora Lise Deharme, musa del surrealismo, y veinte fotomontajes del artista Claude Cahun (Lucy Schwob), publicado en 1937 y reimpreso en facsímil en 2004. Ambos libros expresan una afición por la exploración textual y visual de elementos que se encuentran entre lo real, lo mágico, lo onírico y lo lúdico, renovando los mecanismos utilizados en el libro ilustrado contemporáneo. Lo que une las obras de estas artistas separadas por tantas décadas es la búsqueda por desestabilizar la percepción de la realidad, provocar una experiencia que desate los sentidos y politizar la cuestión del género sexual, en el sentido de que es tomado como una camisa de fuerza contra la libertad de los cuerpos.

En Solo queda saltar (2019), en el año de 1948, las hermanas Celia e Isolina emigran desde Finisterre (Galicia) hacia la provincia de Buenos Aires a vivir con su tío Juan, que había llegado años atrás, a quien las dos nunca habían visto antes. Vienen heridas por la España franquista, que las había condenado a la pobreza, la violencia y a sobrellevar la muerte de sus padres. Ahora huérfanas, se cuidan entre ellas en un país de oportunidades y desafíos donde tratan de reconstruirse como pueden. Celia ayuda al tío en su almacén de ramos generales y luego vuelve a estudiar y a ambicionar ser profesora. La niña Isolina encuentra en Ignacia, hija de una mapuche, un sostén contra los prejuicios que enfrenta un inmigrante.

\footnotetext{
${ }^{5}$ Las muñequitas hechas de alambre, hilo y tul protagonistas de las fotografías se presentan en escenarios minimalistas que se asemejan a la práctica surrealista de los fotomontajes. Los objetos y figuras parecen simular la realidad, principalmente por el uso de objetos doméstico (botones, molino de café, máquina de coser, miniaturas de tazas, gafas, entre otros), pero las referencias a la tradición del teatro de sombras y de marionetas, que un adulto puede evocar, el uso de efectos ahumados y la captura de ángulos y marcos sugestivos logran que florezca un mundo particular en la imaginación de niños y adultos.
} 
En el medio social en donde transcurre buena parte de la historia, o sea Chivilcoy, una ciudad de la pampa, las protagonistas conviven con otras colectividades extranjeras y con los pueblos originarios. De esa manera, Lojo retoma las cuestiones en torno a la construcción de la identidad nacional argentina, yendo más allá, en virtud de su elaborada escritura que elige algunos elementos simbólicos como "las Siniguales" para reforzar poéticamente nuestra condición nómada e incompleta.

Además de todos los avances y nuevas proyecciones abiertas sobre un país ajeno, el pasado acecha a Celia con una circunstancia traumática, que se va revelando por medio de fragmentos de recuerdos y sueños. La trayectoria en el exilio se les hace menos difícil gracias a mujeres fuertes y aguerridas, como las gallegas Trinidad y Carmen Brey, la mestiza Isidra y la señora Angelita que las impulsan a seguir adelante.

En los cuadernos de Isolina, leemos otra época, atravesada por el terror de la dictadura militar y la desaparición de personas. En él ella nos cuenta cómo encontró las páginas escritas por su hermana. La narración avanza hacia el presente, cuando Isolina, médica veterinaria, decide regresar al hogar anhelado, en dónde intenta simbólicamente restituir el hueco dejado por la perdida y la añoranza.

Las puntuales cuestiones genéricas y la breve presentación del corpus me permitirán, en el siguiente apartado, relacionarlas con la necesidad de narrar lo perdido, expresa en el plan metafórico de la lectura conjunta que haré entre algunos textos.

\section{Brevedad y memoria: la necesidad de narrar}

Como reflexioné antes, la realidad fronteriza entre sueño y realidad es perseguida por la voz poemática de los textos de la sección "Visiones", que en muchos casos se asoma al reverso del mundo y mira un mundo familiar escindido por la perdida. En los textos de ese apartado, las imágenes de campo de batalla y guerras, asociables a eventos históricos de un lado y otro de la frontera transatlántica, crean un ambiente estriado por la desterritorialización. Es entonces que la escritura y la imaginación surgen como puentes entre los supervivientes y la realidad. Como afirma Seligman-Silva (2008), la literatura es la que mejor acoge los testimonios de quienes sufrieron un trauma. Sus hablas fragmentadas, asimétricas y llenas de silencios, mal comprendidas en las esferas del derecho y las instituciones jurídicas, encuentran en las artes un espacio de expresión amplio para las memorias del trauma, a causa del poder representativo de los signos lingüísticos.

En este punto de la relación entre el trauma y su narrativa, signo plural en Solo queda saltar, podemos encontrar en el segundo poema del apartado "La palabra muda", de "Visiones" (Lojo, 2011: 220) la continuidad de la trama. El texto indica la conjunción de una acción individual y colectiva atravesada por la violencia del gobierno del momento y la experiencia subjetiva de reelaborar el desajuste cultural. Es un texto generado desde la perspectiva de lo que sucede alrededor o dentro de los sueños. La exploración del material de los sueños se superpone a las imágenes que parecen querer organizarse de manera narrativa, pero que se verticalizan al tocar significados más profundos que una simple peripecia. Los primeros dos párrafos nos remiten al entorno escolar y el desajustado sentimiento de vivir en una "patria prestada" (Lojo 2014: 107) o "transitoria", acentuado en la transmisión del valor patrio del ritual inaugural de cantar el himno nacional delante de la bandera:

Llegan los compañeros hacia las gradas vacías; ellos no son moradores aún, ni son huéspedes. Transcurren en este reino transitorio: el amargo mundo escolar, que rige la bandera. Alguien ha dicho: es la patria, y cantamos en la luz macilenta, sobre el gozo invisible de los pájaros, únicos habitantes de la mañana ciega (Lojo, 2011: 220).

Este gesto tiene la intención de estandarizar el sentimiento y la función de cada ser que se está preparando para el combate en defensa de la patria: "Siendo diversos nos vemos forzados a la igualdad momentánea, al uniforme sonido redondo" (Lojo, 2011: 220). Y entonces, esta "palabra muda" persigue su trazado en Todos éramos hijos (2014). Protagonizada por Frick, "inquilina de una patria prestada" (Lojo 2014: 107), la novela comienza con la descripción de su primer día de clase, caracterizado por el mismo ritual patriótico y el sentimiento de insuficiencia e inseguridad. Con el gesto de mudez, por sentirse enajenada de su origen familiar y de la patria del exilio, el narrador nos informa que: "Se resignó. Intentó concentrarse en la ceremonia inaugural, probando las primeras bocanadas de aire que solo se respiraba en la escuela [...]" (Lojo, 2014: 13). Luego, las puertas físicas se abren y un "microclima" de olores acres hace a la visionaria asociarlos con los olores de la guerra: "Abren las puertas internas y sube el polvo de las escaleras: ácido signo sacrificial y espeso como el humo reseco de los fuegos. Me digo: estos combates de la tierra aguardan, la mutua devastación en el penoso y múltiple ascender" (Lojo, 2011: 220). 
A lo largo la novela Todos éramos hijos, el problema de la identidad se vuelve más espeso con la adolescente Frick, dividida entre la cultura española transmitida en el hogar y la cultura argentina del ambiente escolar. El trasfondo histórico del relato es la década de 1970, el período de mayor violencia y terror de la dictadura militar. En este punto, el personaje cumple quince años y atraviesa un momento de profunda crisis existencial. En uno de sus combates interiores, se aloja en la habitación trasera de la casa, donde convergían todos los jardines y patios, y

... Sobre ese cielo, al trasluz del sol decreciente, desfilaban las sombras: los que antes habían vivido, los que tal vez venían a vivir. La caravana nunca cesaba, escondida bajo el día brillante, y solo en esa frontera delicada entre luz y tiniebla podía ser percibida (Lojo, 2014: 76)

El dibujo de otra realidad, así como en "Transparencia" del apartado "Esperan la mañana verde", es enmarcada por lo gestual "y multisensorial y se revela mediante una lente poderosa que captura una dimensión oculta [y] exige la actitud de la visión" (Marques, 2019: 238, traducción mía).

La defensa del sujeto femenino en los textos de "Visiones" y Todos éramos hijos será a través de las palabras, es decir, la literatura. Las situaciones conflictivas del período escolar presentadas en la microficción "La palabra muda" no terminan con el final de la visión o, mejor dicho, la visión sigue afectando al "tú": "Transcurre el plazo de la visión; los combates inquietan aquellas aguas lúcidas; los cascos de caballos, los campamentos y las naves ancladas. Todo asedia tu centro. Atacarás también. Es necesario". (Lojo, 2011: 220).

Lo que asalta la tranquilidad de la visionaria son las imágenes de estos fragmentos bélicos (los cascos de los caballos, los campamentos y los barcos anclados) que surgieron del sueño y permanecen allí en la superficie del mundo real. Una vez más, el narrar es una actividad elemental, en el sentido de que la supervivencia de los que viven una situación radical de violencia depende de ello (Seligmann-Silva, 2008: 66).

En Solo queda saltar la experiencia traumática de Celia, testigo del abuso sexual de su prima Eulalia, la persigue en una pesadilla. El sueño, prototipo narrativo, es configurado estéticamente en fragmentos intercalados en la novela, a través de la repetición de escenas contrastantes y metonímicas, que nos hacen entrar en un mundo "con el corazón latiendo sin palabras" (Suárez Araúz, 2010: 23). Una creación resonante de sentidos, de signos polivalentes, un mundo interior que nos pone en contacto con las formas visuales del horror:

... Pero no me duelen las espinas, sino el miedo. Sigo corriendo, sin aire, mientras en la mitad del pecho se me clava otro arbusto de cristales rotos. Algo me empapa los muslos, resbala, cálido, las los tobillos. Solo cuando alcanzo las piedras del muro bajo que rodea la finca me atrevo a tocarme. Detrás de mí, todavía lejanos, se oyen los gritos de los hombres que me cazan [...]. (Lojo, 2018: 9).

Celia alcanza a escribir un diario -forma fragmentaria, no nos olvidemos, que organiza la realidad de lo vivido y lo imaginado- y luego una carta dejada para Isolina, en la que consigue cargar de sentido su trayectoria y saltar el muro del silencio. Narrar lo perdido, lo traumático de las catástrofes históricas, de las violencias estructurales, del sentimiento de extranjería es atacar o saltar, según la lectura ficcional que Lojo hace de la realidad. Es igualmente un modo de ordenar, bajo el peso de las rupturas de su historia familiar, a su propia existencia. Según señala Seligman-Silva (2008:70 traducción mía): "La imaginación es llamada como arma que debe venir en ayuda de lo simbólico para enfrentar el agujero negro de lo real del trauma. El trauma encuentra en la imaginación un medio para su narración. La literatura es llamada ante el trauma para prestarle servicio".

El poder de representación de los signos lingüísticos elaborados artísticamente, a su vez, genera ese efecto en los lectores, es decir, gracias a la capacidad de la ficción de ordenar el extrañamiento y el caos delante de ese "agujero negro", de las pérdidas y violencias, que nos impacta la percepción con su forma. No solo la impacta, sino que la amplía a horizontes invisibles, según argumento a continuación.

\section{La mirada singular: las existencias nómadas, fronterizas e inacabadas}

David Lapoujade, en Las existencias menores (2018), con el que dialogo en este análisis de las formas y temas de la escritura lojiana, analiza la pluralidad existencial propuesta por el filósofo Étienne Souriau (1892-1979) y reflexiona sobre su inventario de los muchos modos de existencia. Entre ellos están los 
fenómenos, las cosas, los imaginarios y los virtuales. Este último es ejemplificado como parte del proceso de creación artística. El artista entrevé la posibilidad de desarrollar un tema por medio de una partícula flotante al filo de una conversación, en "una semilla más simple, el átomo de verdad, de belleza, de realidad, apenas visible a la mirada ordinaria" (James apud Lapoujade, 2018: 31). Esa partícula flotante es la manifestación de lo virtual que puede tomar formas variadas, una vez que contiene múltiples posibilidades poéticas.

Esa realidad apenas visible puede ser iluminada por una chispa creativa; no al azar esta es una de las metáforas para la brevedad microficcional, empleada por algunos autores del género. La creación de esa realidad aparece figurada, por ejemplo, en relámpagos y destellos que representan, muchas veces, una vía simbólica para la superación de una condición errante, generada por conjeturas históricas o subjetivas. En ese sentido, el nomadismo, tema fundamental en la poética lojiana, se complejiza en algunos textos con la búsqueda de un centro esencial, lleno de sentidos ambivalentes y limítrofes, que instalan a los personajes en "un nuevo orden cósmico temporal y espacial", como señala Marcela Crespo Buiturón (2008: 173) y les permiten superar el dilema del regreso, gran utopía del exiliado. Así, cobra especial interés el poder iluminador y visionario del arte, en especial en las formas breves, como expresado por el personaje Rosaura, de la novela La pasión de los nómades (1998), con las siguientes palabras: "Que más allá, en la gran intemperie donde se agotan las palabras humanas, se abrían las verdaderas puertas de la percepción, la mirada que era realmente la mía y a la que a veces, sólo a veces, como decía Lucio, acceden en relámpagos los poetas" (Lojo, 2008: 216).

Con eso entramos en el reino de la ficción que incluye a los seres imaginados y soñados, "a veces casi tan sólidos como cosas", como nos lo recuerda Lapoujade (2018: 30). En ese dominio, los virtuales siguen operando de manera "imperiosa como cualquier otro tipo de realidad" (Lapoujade, 2018: 30) y la vuelven inacabada y cambiante. Para percibir esa existencia es necesario reorganizar la mirada para ver "las innumerables aberturas dibujadas por los virtuales" (Lapoujade 2018: 38). Como ejemplifica Lapoujade (2018: 38), "un paseante distraído no ve el esbozo de un puente virtual en una sucesión de piedras alineadas a través de un arroyo". De este modo, entre la microficción de Lojo y sus narrativas, en especial en Solo queda saltar, distingo las transformaciones, los aumentos o disminuciones de temas y figuras que la virtualidad dibuja con un trazado rugoso.

El camino que veo dibujarse entre la microficción de Bosque de Ojos y el Libro de las Siniguales, luego ampliado en Solo queda saltar, pasa por el tema del alcance de una visión que abarca la multiplicidad del ser, imposible para el pensamiento racional, que encontramos presente en la microficción "Los ojos de dios", de Esperan la mañana verde (1998). En este punto, quiero acercar el universo impalpable de las Siniguales a lo que he mencionado antes de la virtualidad y la realidad. Mi idea es asociar esta problemática existencial, en el sentido atribuido por Souriau (1930), al extrañamiento provocado por la experiencia del exilio y su replanteamiento por medio de la imaginación, es decir, la literatura.

Para eso, es necesario recordar que en esa microficción Lojo (2011: 87) describe los ojos de Dios como un órgano fantástico:

\section{Ojos de Dios}

Los ojos de Dios crecen en las cavidades como los hongos bajo la humedad de las lluvias. Nacen sin cultivar, indisciplinados y múltiples, para ser devorados por animales pequeños o por niños cazadores de lagartijas.

Cada ojo es un mundo minúsculo que sólo puede verse al trasluz. Pero nadie se detiene a mirarlo y el diseño profundo y delicado de todo un cosmos desaparece bajo los colmillos de un perro o los dientes de un chico, con un sabor agridulce y una consistencia viscosa que estimula la desazón y la melancolía.

Los perros vagabundos que anuncian funerales, los hombres atrabiliarios y las mujeres estériles son -dicenlos que comieron ojos de Dios y ahora ambulan por los bordes de la vida, ciegamente rencorosos y tristes porque alguna vez tuvieron y perdieron la más secreta irradiación del mundo.

Las pequeñas esferas radiantes que contienen el diseño de todo el cosmos son devoradas por seres que están alienados o extrañados de sí mismos. La inversión de la escala suprema del ojo divino disimula su importancia para los humanos. Quienes prueban estos ojos tienen la sensación del momento cuando somos despertados de un sueño en el que estábamos a punto de lograr algo precioso que se nos escapó, como un espejismo (Marques, 2019).

La sensación de interrupción de los sueños y de la ilusión perdida, presente en otros textos, es reinterpretada en El libro de las Siniguales y del único Sinigual, una vez que Isolina, la niña/vieja, persigue la visión esquiva de las pequeñas criaturas llenas de ojos, dejando quedarse atrapada por la pasión de conocerlas, mientras ignora que viven en el costurero de su casa: "[...] Isolina sigue buscando los ojos de Dios que crecen en lugares escondidos, como los hongos bajo la humedad de las lluvias, aunque no sabe qué hará con ellos si los encuentra" (Lojo, 2016: s/f). 
El topos del bosque húmedo, una referencia geográfica a los bosques de Galicia de donde proviene la ascendencia gallega de la autora, corresponde en otros textos a la imagen del laberinto, como podemos leer en "Curioso destino", microficción de "Esperan la mañana verde" o de la biblioteca como lo asocia la narradora de Árbol de familia (2010), entre muchos otros.

El otro enlace con el Libro de las Siniguales y del único Sinigual que presenta Solo queda Saltar es cuando se festeja el carnaval en las pampas y el tío Juan participa de la festividad con un carro de aderezos en el que, entre otros, irían sus sobrinas con disfraces. Después de que el tío Juan rechazara la intención de una de sus empleadas, la conterránea Trinidad, de vestir a Isolina de traje tradicional gallego, la niña aparece vestida "debajo de un velo gris oscuro que se le ajusta sobre la cara como una máscara de gasa" en una composición de "retazos múltiples que llega desde su cuello hasta los pies, en fragmentos multicolores de raso, de satén, de algodón, de paño" (Lojo, 2019: 50). Delante del espanto del tío, que no consigue identificarla ni con un duende, ni con una bruja ni mucho menos con un hada, la niña contesta que va vestida de una Sinigual.

El simbólico festejo del carnaval permite que el discurso literario plantee el tema de la identidad en una clave que abarca la visión del adulto y del mundo infantil. De un lado, Juan rehúsa vestir a la sobrina de gallega, desconfiado de la folclorización de un modo de existir que no se construye desde afuera, y de otro lado, le permite a la niña expresarse en un mundo ajeno por medio de su ropaje múltiple, que no retiene una identidad estable. En este punto, el diálogo entre tío y sobrina retoma parte de lo narrado en El libro de las siniguales y del unico Sinigual (Lojo, 2016: 51):

-¿Y qué hacen las Siniguales?

- Son.

- ¿Qué son?

- Siniguales. No se parecen a nadie, sino a ellas mismas.

- ¿En qué libro las viste, en que cuento?

- No están en los cuentos. Las vi en Fisterra. En las rocas, al lado del mar. Antes de que viniéramos a América.

$-¿ \mathrm{Ah}, \mathrm{sí}$ ?

- Por eso me conformé con venir. Para volver a encontrarlas.

- ¿Aquí?

- Son muy viajeras. Y muy pequeñas. Cabían en la palma de mi mano. Olían bien. A perfume de canela, a fillaos recién hechas. Me calentaron la mano, que estaba helada. Me quitaron las penas. Pero se fueron, en una dorna que volaba. Y cruzaron el mar, en dirección de América. No saben que estoy aquí. América es tan grande. Si me visto como ellas, a lo mejor se enteran y vienen a buscarme.

La festividad del carnaval no es elegida al azar. Por ella pasean una variedad móvil de personas (máscaras), en muchos casos híbridos de hombre y animal, ya que representa la fiesta de la carne y de lo instintivo. Los elementos plásticos del mundo carnavalesco se comunican con el bestiario medieval, uno de los géneros que alimentan El libro de las Siniguales. Los animales que solían aparecer en estos textos medievales eran fruto de la imaginación y de la inclinación enciclopédica al revés, pues al contrario de valorar una identidad real y específica, prefería las criaturas imaginarias e híbridas.

Lejos de agotar las separaciones efectuadas por los hombres entre su animalidad "racional" y la de los "irracionales" o seres imaginarios y reales, la narrativa me lleva nuevamente a acercarme al juego proyectado sobre la naturaleza de las Siniguales, más precisamente sobre las cuestiones que estoy enfatizando, esto es, de la virtualidad.

En las páginas dobles de la "Supervivencia de las Siniguales" una luz anaranjada, objetos agujereados, brocas circulares y gradas crean un escenario amenazante y hostil. El diálogo entre la imagen y el texto está de acuerdo con lo que Mariane Berissi (2014: 7, traducción mía) observa al comentar las composiciones más recientes del álbum ilustrado: "Si al principio el texto parece redundante en comparación con las imágenes que parece describir, rápidamente se hace evidente que las imágenes mentales sugeridas por el texto no pueden ser del orden visible y son las que enriquecen el álbum". El énfasis en el texto literario, en muchos momentos, permite esta apertura a significados menos visibles como la cuestión implícita a lo largo del álbum sobre el derecho a existir y no simplemente a ser real o irreal, como uno podría pensar sobre la naturaleza de las Siniguales.

Por ese prisma, el texto se politiza para tratar de la condición de los exiliados de todos los órdenes, frágiles amenazas contra la rigidez homogeneizadora que cementó distintos proyectos de control y de sujeción. Esto refuerza mi argumento de que el blanco de la cuestión, apenas visible, es el de las existencias rechazadas, "expulsadas por la realidad misma. O la parte que está en el mundo ya no les pertenece, el 
mundo los ha desposeído de antemano", según la definición de David Lapoujade (2018: 84) de los seres desposeídos. Estos seres borrados por la historia, debido a su naturaleza híbrida, su condición nómada y fuera de género, señalan a Isolina, la insólita, y le permiten manejar su crisis de identidad al aceptarse a sí misma como múltiple y singular. $Y$ en este último sentido, el texto adquiere toda su densidad en relación con la imagen visual y mental de ambas las narrativas.

A través de su sensibilidad poética, Lojo establece la conexión con desposeídos de otros tiempos -como la niña Ignacia, de ascendencia mapuche-sobrevivientes a las adversidades de la vida y de los hombres, tal como Isolina, que reflexiona en su cuaderno: "Sus antepasados indios nunca se fueron. Los echaron y tuvieron que resignarse. Aunque también nos echaron de algún modo a nosotras. A los perdedores de todas las guerras" (Lojo, 2018: 129). Esa condición excéntrica es compartida entre ambas señoras (Isolina e Ignacia): "Dos viejitas de poco más de metro y medio, tomadas de la mano, apoyadas en bastones de peregrino, tanteando despacito las rocas con nuestras botas de goma" (Lojo, 2018: 105). Diminutas, con bastones, peregrinas y singulares reclaman su existencia en toda su naturaleza incompleta y rugosa: la concretización de la dimensión virtual, es decir, una posibilidad de lo real que requiere su existencia por medio de la creación de una percepción singular, que es solo invisible para el discurso dominante, que las hace invisibles.

Por fin, al encontrarse con las Siniguales, Isolina recobra la visión de la infancia:

Antes de bajar por las escalinatas, Ignacia abre inesperadamente su cartera. Algo mínimo, leve, destellante, familiar, se escapa de ella, queda suspendido en el aire unos segundos, flotante bajo la luz del atardecer con un eco de música y un olor de canela. Cuando quiero atraparlo, definirlo, volverlo a mirar, titila y desaparece. (Lojo 2018: 148)

Esa abstracción destellante deviene perceptible en "la superficie reflectante de movimientos, de desplazamientos íntimos, inducidos por un cambio de escala en la percepción" (Lapoujade 2018: 89). Y lo que se cuestiona en el discurso literario es la idea de las taxonomías rigurosas y las clasificaciones definitorias.

En este contexto, al final de la novela, por medio de la narradora Isolina, se retoma el enlace con El libro de las Siniguales y del único Sinigual cuando ella intenta definirlo a través del comentario metaficcionl: "Un libro que sería de ciencia, [...], si no tuviese que usar instrumentos ajenos a mi oficio: la adivinación y la poesía" (Lojo, 2018: 150). El tenue límite entre la ciencia y la poesía es una frontera más que la autora hace visible.

\section{Palabras finales}

De esta manera, concluyo que entre la colección de microficciones, Bosque de Ojos y Solo queda saltar, la escritura de Lojo esboza de manera fractal una arquitectura virtual que nos hace ver múltiples experiencias vividas. Hacer ver es hacer existir. Su percepción no se reduce a lo subjetivo o lo individual, sino que entra en perspectiva con otros modos de existencia, según defiende Souriau, para quien "percibir no es observar desde fuera un mundo desplegado delante de uno mismo, sino por el contrario es entrar en un punto de vista [...] La percepción es participación" (apud Lapoujade, 2018: 40).

La fuerza del texto literario, en muchos momentos, permite abrirse a temas menos visibles. Uno de ellos, reforzado a lo largo del álbum mediante la naturaleza paradójica de los Siniguales y su esquiva materialidad, enfatiza el derecho a existir de ellos, como metáfora de los desposeídos, y replantea en clave poética cuestiones identitárias.

Para alcanzar eso, Lojo y Beuter juegan con construcciones ambiguas, en las que la naturaleza de las Siniguales es atravesada por lo irreal y lo virtual, es decir, se forjan potencialmente como reales a través de la fotografía. Esto refuerza lo que entiendo como el núcleo de la problemática que rodea la construcción de la identidad de los marginados por la historia: el derecho a existir y el hecho de existir. Pocos visibles son parte de las existencias rechazadas, o en las palabras de Lapoujade (2018: 84), seres "expulsados por la realidad misma. O la parte que está-en-el-mundo ya no les pertenece, el mundo los ha desposeído de antemano". Estos seres borrados por la historia, debido a su naturaleza híbrida, su condición nómada y fuera de género, señalan a Isolina, lo inusual, y le permite manejar su crisis al identificarse como múltiple y singular. 


\section{Referencias bibliográficas}

Berissi, Marianne (2014), "La tentation littéraire de l'album”, Hors Cadre[s], n. 15, octobre, págs. 6-9.

Brasca, Raúl (2000), "Los mecanismos de la brevedad: constantes y tendencias en el microcuento", El cuento en red, $\mathrm{n}^{\circ}$ 1. Disponible en: http://cuentoenred.xoc.uam.mx/tabla_contenido.php?id fasciculo=251

Crespo Buiturón, Marcela (2008). Andar por los bordes. Entre la historia y la ficción: el exilio sin protagonistas de María Rosa Lojo. Biblioteca Virtual Miguel de Cervantes. Disponible en: http://www.cervantesvirtual.com/obra/andar-por-los-bordes-entre-la-historia-y-la-ficcion-el-exilio-sin-protagonistasde-maria-rosa-lojo--0/

Deharme, Lise (2004). Le coeur de Pic. Fotografías de Claude Cahun. Rennes: Edición Memo.

Garramuño, Florencia (2014). Frutos estranhos: sobre a inespecificidade na estética contemporânea. Trad. de Carlos Nougué. Rio de Janeiro: Rocco.

Lagmanovich, David (2006). El microrrelato: teorias e historia. Palencia: Menos cuarto.

Lojo, María Rosa (2011). Bosque de ojos. Microficciones y otros textos breves. Buenos Aires: Sudamericana.

Editorial Mar Maior. (2016). El libro de las siniguales y del único sinigual. Fotografías de Leonor Beuter. Buenos Aires:

(2008). La pasión de los nómades. Buenos Aires: Debolsillo.

-----, -------- (2018). Solo queda saltar. Buenos Aires: Santillana.

-----, -------- (2014). Todos éramos hijos. Buenos Aires: Sudamericana.

---, ----------- (2002), “Una escritora de dos mundos. Mínima autobiografîa de una exiliada hija”. Revista digital Al Margen, noviembre, 2002. Disponible en: http://www.almargen.com.ar/sitio/seccion/literatura/lojo/

Lapoujade, David (2018). Las existencias menores. Trad. de Pablo Ires. Buenos Aires: Cactus.

Marques, Gracielle (2019), "Poética do esquecimento: uma aproximação à microficção de María Rosa Lojo", Revista Soletras, 38.2, Rio de Janeiro, págs. 228-248.

Piña, Cristina (2010), "María Rosa Lojo: Poema en Prosa, Microficción y Microlegendarium”, Revista Gramma, 47, XXI, Buenos Aires.

Pollastri, Laura (2007). El límite de la palabra: el microrrelato argentino contemporáneo. Palencia: Menos cuarto.

Seligmann-Silva, Márcio (2008), "Narrar o trauma: a questão dos testemunhos de catástrofes históricas", Psicol. clin., Rio de Janeiro, vol. 20, nº 1, págs. 65-82. Disponible en: http://dx.doi.org/10.1590/S0103-56652008000100005

Shua, Ana María (2017). Cómo escribir un microrrelato. Barcelona: Alba editorial.

Suárez Araúz, Nicomedes (2010). Loén: un mundo amazónico olvidado. Antología de la obra loeniana y la estética de la Amnensis. Santa Cruz de la Sierra: La hoguera.

Zavala, Lauro (2006), "Fragmentos, fractales y fronteras: Género y lectura en las series de narrativa breve", en Pablo Brescia y Evelia Romano (coords.). El ojo en el caleidoscopio. México, DF: Universidad Nacional Autónoma de México, págs. 35-52. 